\title{
Examining A Lump Sum Tax and Optimal Tax Theory
}

https://doi.org/10.21272/sec.5(4).166-171.2021.

Richard Fast, ORCID ID: https://orcid.org/0000-0002-9779-1659

M.A. Economics 2022, Troy University, USA

\begin{abstract}
This paper will cover an overview of Optimal Tax Theory with a special emphasis on the benefits and drawbacks of a Lump Sum Tax. Covering the work of Ramsey (1927), Mirrlees and Diamond (1971a, b), Slemrod and Yitzhaki (1996), Samuelson (1954), Lindahl (1919, 1958) and others, the paper compares and contrasts the foundational works in Optimal Tax Theory on a Lump Sum Tax with more recent literature. The purpose of this analysis is to shine new light on how a Lump Sum Tax might be better implemented in the future. Also considered are to how to maximize efficiency in a tax scheme while minimizing the political unpopularity of such an unequitable tax, in particular how a Lump Sum Tax ushered in the end of Margaret Thatcher's political career. While the ultimate goal of any tax-collecting agency is to tax ability, this is not possibile since high-ability, and hence, high-income, earners will attempt to disguise themselves as low-ability (low-income) to minimize their tax burden. Using the Ramsey Rule (1927) and Slemrod and Yitzhaki's (1996) "marginal efficiency cost of funds", I compare the Lump Sum Tax to other taxation schemes, such as a progressive tax, which is generally seen to be more equitable to those who are concerned with social justice, and a regressive tax, which is generally seen to be more efficient to those who are concerned with minimizing their tax burden. Also considered are efficiency concerns regarding enforcement and the costs associated with enforcement of these other tax schemes; a LST would dramatically reduce enforcement costs and the confusion that comes with calculating progressive tax brackets. I argue that it is not enough to consider the impact and efficiency of such a tax, but that the political ramifications must also be considered; due to social welfare concerns, such a tax must also be politically feasible in order to be successful. This paper will be of benefit to anyone who is interested in making the current U.S. tax regime more efficient while addressing equity concerns in its implementation, citing historical examples including the U.K., Italy, Romania, and Switzerland.
\end{abstract}

JEL Classification: D60, H21, H22, H71.

Keywords: Optimal Tax Theory, Lump Sum Tax, efficient tax, equity, social welfare, marginal efficiency of funds.

Cite as: Richard Fast (2021). Examining A Lump Sum Tax and Optimal Tax Theory. SocioEconomic Challenges, 5(4), 166-171. https://doi.org/10.21272/sec.5(4).166-171.2021.

Received: 30.08.2021 Accepted: 15.11.2021 Published: 30.12.2021

Copyright: (C) 2021 by the author. Licensee Sumy State University, Ukraine. This article is an open access article distributed under the terms and conditions of the Creative Commons Attribution (CC BY) license (https://creativecommons.org/licenses/by/4.0/).

\section{Introduction}

This paper will cover an overview of Optimal Tax Theory (OTT) with a special emphasis on the benefits and drawbacks of a Lump Sum Tax (LST). Covering the work of Ramsey (1927), Mirrlees and Diamond (1971a, b), Slemrod and Yitzhaki (1996), Samuelson (1954), Lindahl (1919, 1958) and others, the paper compares and contrasts the foundational works in OTT on a LST with more recent literature, including Bishop (2004), Tam (2004), Black (2009), Mankiw et al. (2009), Petre and Bontas (2009), Craciuneanu and Savoiu (2010), Dobranschi et al. (2017), Paolella and Angelini (2018), and the Swiss Federal Department of Finance (2021). By comparing a LST to a progressive and regressive tax scheme, we see how concerns of efficiency and equity 
come into play, particularly in the context of political economy and feasibility. The purpose of this analysis is to shine new light on how a LST might be better implemented in the future. Also considered is to how to maximize efficiency in a tax scheme while minimizing the political unpopularity of such an unequitable tax. This paper will be of interest to anyone who is interested in making the current U.S. tax regime more efficient while addressing equity concerns in its implementation, citing historical examples in the U.K., Italy, Romania, and Switzerland.

The rest of the paper will be structured as follows: Part II will give the background of OTT, Part III will give an overview of what a LST is, Part IV will cover how a LST could be implemented, and Part V will provide a conclusion. Finally, attached are works cited.

\section{Literature review}

This section will be a review of the literature on Optimal Tax Theory and and a Lump Sum Tax. The purpose of this section will be to see what issues have been previously identified and what are areas for new discovery.

Optimal Tax Theory was pioneered by Frank Ramsey's (1927) "A Contribution to the Theory of Taxation" in which he introduced the concept of an optimal commodity sales tax. If a sales tax were too high, consumers would spend less and substitute those purchases for other activities. Since virtually all taxes are inherently distortionary in some way, Ramsey sought to identity a tax that would maximize tax revenue while minimizing its distortionary effect. Ramsey's policy prescription limited tax collectors very narrowly, instead of allowing policymakers to consider all options. This sparked a re-examination of tax schemes all together, from sales tax to income tax. Baumol and Bradford (1970) Mirrlees and Diamond (1971a, b) proposed an alternative that allowed policymakers more flexibility for any given situation by establishing a tax system that solved the problem of higher taxes disincentivizing high-income earners from working more. This new tax system would take incentives into consideration such that high-income earners would not be tempted to hide their ability; while high-income earners would see larger average taxes, their marginal tax rate for each tax bracket would be lowered.

\section{Optimal tax theory}

Optimal tax theory (OTT) considers questions such as: Given that people want public goods and services, what is the best tax regime to provide these goods and minimize the excess burden associated with that tax regime? OTT is also concerned with the positive principles of taxation: What are the effects of a tax? Who bears the burden of a tax? What are potential unintended consequences of a tax? With regard to tax incidence, who pays the tax matters because that will determine how individual behavior is distorted through price changes. Mirrlees and Diamond (1971a, b) lay out eight stylized facts surrounding OTT: 1) optimal marginal tax rate schedule depends on the distribution of ability, 2) optimal marginal tax rate schedule could decline at high incomes, 3) tax ability to minimize excess burden, 4) optimal redistribution rises with wage inequality, 5) optimal taxes should depend on personal characteristics as well as income, 6) only final goods should be taxed, and taxed uniformly, 7) the optimal capital gains tax is zero, and 8) in a complex world, the tax policy should match its complexity. OTT is a normative approach to taxation as people like receiving public benefits but dislike paying for them. (Slemrod 1990) Finally, an important question in OTT discussion is how to define income. Taxes will differ depending on what definition of income is used; for example, whether to include "imputed income" such as in-kind benefits and rental income. If income is defined as benefits accrued from one's occupation and not as a dollar amount from labor incurred, then a company car that an employee takes home is legitimately determined as "income."

There are two distinctions to be made with regard to who pays the tax: statuary tax burden and actual tax burden. Statutory tax burden refers to who the law says must pay the tax. Actual tax burden refers to who actually pays the tax. Who actually pays the tax depends on the elasticities of supply and demand. The elasticities of demand determines whether the consumer or the firm pays more of the tax. Taxes to firms are no different than a cost of doing business (cost of production). That cost affects supply and demand with producers lowering production; the tax acts as a disincentive to sellers. This creates a shift inward by the full amount of 
the tax. With a tax on business, it does not matter who the tax is imposed upon, both the firm and the consumer bear the same proportion of the tax. Corporations do not pay taxes, but instead pass them off to consumers. One critique of OTT is that the point of taxation is to increase revenue, which may not coincide with, or be reflective of, maximizing social welfare. At the end of the day, governments are trying to maximize tax revenue and firms are trying to minimize their tax burden.

Baumol and Bradford (1970) examine the distortionary effect that a sales tax has on consumption. Since the optimal sales tax rate is zero but the government still needs to collect revenue, they assert that any sales tax is second-best to the optimal, creating "quasi-optimal" pricing, which they demonstrate with four examples trying to arrive at a Pareto optimal solution. The authors conclude that the closest outcome to an optimal solution is to differentiate between prices and marginal cost. This is insightful because it shows that a tax, no matter whether it is on commodities or income, will always less than optimal but at least it can be implemented in a leastdistortionary way. Raising taxes is predictably and systematically unpopular, everywhere but especially in the U.S., and so it can pose a thorny political challenge for politicians trying to raise revenue for government programs.

\section{A Lump Sum Tax}

Within optimal tax theory, a lump sum tax is a situation in which everyone pays the same dollar amount in taxes, regardless of high or low income. (Bishop 2004) This tax scheme is in contrast to a progressive income tax in which the tax gets bigger for each bracket of additional income, and in contrast to a regressive income tax in which the tax gets smaller for each bracket of additional income. A lump sum tax is unique in comparison because it is the only tax that is non-distortionary. Ramsey (1927) shows that an optimal tax is one that minimizes excess burden through inverse elasticities. Excess burden leads to deadweight loss, which is distortionary and creates a substitution effect. Ramsey (1927) also suggests increasing revenue through a commodity tax to maximize social welfare. The Ramsey Rule creates a model with only one consumer, effectively assuming away the problem of equity, and tests optimal tax rates on commodity spending by that one consumer in order to generate the required level of tax revenue. (Black et al 2009) The Ramsey Rule has two underlying assumptions: 1) elasticity of supply is not taken into account, and 2) goods are independent. The result is that optimal taxes reduce the compensated demand for each commodity. The Ramsey Rule further stipulates that with inverse-elasticity, goods whose elasticity of demand is high should be taxed lightly and goods whose elasticity of demand is low should be taxed heavily. This will minimize excess burden associated with a tax. It is also efficient because it distorts behavior the least. Mirrlees and Diamond (1971a) assert that an optimal income tax is a proxy for taxing ability, which is what the government really wants to tax, and from that tax and government production, a social welfare function can be maximized. Taking the first order conditions, Mirrless and Diamond (1971a) show how efficiency can be achieved in aggregate production with various tax schemes that attempt to tax ability via proxy.

There are several problems with trying to tax ability. The first problem is that high ability earners will disguise themselves as low ability to avoid larger taxes. This effect is a net loss for individuals in society because the government is not able to raise as much tax revenue as it needs to fund public projects. It also means that high ability earners will be discouraged from working since the tax can be seen as a punishment for being highly productive. The second problem is that governments are left with the problem of imperfect information and figuring out how to tax ability. A lump sum tax on income would avoid this problem by taxing everyone equally regardless of income amount. Samuelson (1954), building on Lindahl $(1919,1958)$ and others, shows that most economists had neglected the theory of optimal public expenditure and introduced the concept of private consumption goods and collective consumption goods. Slemrod (1990) introduces the concept of optimal tax systems, in contrast to optimal taxation, in which technology and its effect on revenue collection and enforcement (efficiency) is taken into account. Slemrod and Yitzhaki (1996) show that taxation causes deadwieght loss and that an alternative policy evaluation rule, called the "marginal efficiency cost of funds," can redirect taxes to more efficient outcomes. Mankiw et al. (2009) look at the implementation of optimal tax theory across countries over time. The Tax Reform Act of 1986 in the U.S., for example, closed lots of loopholes and deductions. This policy had the effect of taxing more people but at a lower rate, thereby 
increasing tax revenue while decreasing individual tax liability. Mankiw et al. (2009) state that because the tax falls evenly on both the rich and the poor, the poor are disproportionately negatively impacted by the tax. For Mankiw, uniform commodity taxes would be optimal. For that to happen, the assumptions are restrictive because utility functions must be seperable. Imposing commodity taxes would cause people to substitute into leisure. Mankiw would support taxing highly goods that are compliments to leisure, such as snowboards, and taxing lightly goods that are substitutes to leisures, such as work uniforms. However, a lump sum tax avoids the problems of trying to tax ability because it is applied to all income-earners regardless of whether they are high ability or low ability. In this sense, a lump sum tax is very efficient.

In addition, there are both desirable and undesirable aspects of using a lump sum tax to finance government expenditures. On the desirable side, it is non-distortionary (see above analysis), relieves some of the excess burden and deadweight loss of taxation, and is efficient to administer and enforce. On the undesirable side, it is not equitable, unlike a progressive income tax scheme which makes the rich pay more proportionately simply because they have a bigger ability-to-pay (ATP). This in turn makes a lump sum tax politically unpopular and difficult to implement. Regarding ATP, Mises [1998, (1949)] states,

"The actual fiscal policies of all countries are today exclusively guided by the idea that taxes should be apportioned according to each citizen's "ability to pay." In the considerations which finally resulted in the general acceptance of the ability-to-pay principle there was some dim conception that taxing the well-to-do more heavily than those with moderate means renders a tax somewhat more neutral. However this may be, it is certain that any reference to tax neutrality was very soon entirely discarded. The ability-to-pay principle has been raised to the dignity of a postulate of social justice. As people see it today, the fiscal and budgetary objectives of taxation are of secondary importance only. The primary function of taxation is to reform social conditions according to justice. From this point of view, a tax appears as the more satisfactory the less neutral it is and the more it serves as a device for diverting production and consumption from those lines into which the unhampered market would have directed them." (p. 31, Human Action)

A lump sum tax will maximize social welfare and efficiency with no deadweight loss, but at the cost of being regressive. A lump sum tax does not include ATP and is not equitable at all. Such a tax scheme may not be popular with voters and may damage politicians seeking re-election. A lump sum tax shifts the individual's budget constraint but does not change relative prices, making it non-distortionary. This tradeoff between efficiency and equity must always be kept in mind when altering the tax code; some will made better off while others will be made worse off, except for a lump sum tax which is rarely politically feasible. What matters, then, is what are the tradeoffs with which people are willing to live. Additionally, Tam (2004) gives a Humean critique of a lump sum tax - that governments are unlikely to implement a lump sum tax since the tax is for an arbitrary amount, while the size and scope of government continues to grow, meaning that whatever the amount is this year will likely increase with each additional year.

In addition, a lump sum tax affects inframarginal but not marginal behavior. This is because a lump sum tax only impacts the difference between the existing tax brackets, but not on individuals' buying behavior. Suppose prior to the implementation of a lump sum tax, there are five tax brackets. With the introduction of the lump sum tax, those five tax brackets have been reduced to only one. This change in the tax scheme is highly efficient but not at all equitable since it treats the highest earners exactly the same as the lowest earners and those with no income. (Would homeless people be required to pay the tax and if so, how would they pay it?) Mirrlees and Diamond (1971b) state that the optimal number of tax margins is one because it causes the least distortion in relative prices.

With regard to equity, a tax is considered equitable if the tax increases as the individuals's ATP increases, much like a progressive income tax. Holcombe (2004) distinguished between "horizontal equity" and "vertical equity." The former describes a situation in which two taxpayers with equal ATP are charged the same tax. The latter describes a situation in which taxpayers with greater ATP are charged a higher tax. Holcombe (2004) argues that reasonable people might disagree on whether two taxpayers actually have equal ATP (horizontal equity) and how steep taxes should rise with ATP (vertical equity). What is missing from this analysis, however, is a time component and the effect of inflation, which reduces the value and purchasing power of everyone's 
income, regardless of dollar amount. In the United States today (2021), this is especially relevant as inflation is only expected to increase and many consumers are rightfully concerned.

In addition, Mises [1998, (1949)] states regarding a LST,

"A head tax that taxes every citizen equally and uniformly without any regard to the size of his income and wealth, falls more heavily upon those with more moderate means than upon those with more ample means. It restricts the production of the articles consumed by the masses more sharply than that of the articles mainly consumed by the wealthier citizens. On the other hand, it tends to curtail saving and capital accumulation less than a more burdensome taxation of the wealthier citizens does. It does not slow down the tendency toward a drop in the marginal productivity of capital goods as against the marginal productivity of labor to the same extent as does taxation discriminating against those with higher income and wealth, and consequently it does not to the same extent retard the tendency toward a rise in wage rates." (p. 31, Human Action)

\section{Implimentation of a LST}

Finally, from a policy standpoint, a lump sum tax has been implimented previously. Mankiw et al. (2009) point to the United Kingdom in 1989 in which Prime Minister Margaret Thatcher's philosophy of public finance used a lump sum tax, called a "community charge". This charge was imposed on each member of a household, sometimes referred to as a "head tax" or "poll tax" (per-person tax), along with the abolition of all other taxes. Because this lump sum tax was inequitable, it quickly took on sharp criticism and was a contributing factor to the end of Thatcher's political career. Petre and Bontas (2009) show that Romania attempted a LST in 2009. The authors list social cost as one motivation for implementing the tax. Additionally, Switzerland implemented a lump sum tax on the top 0.1\%. (Swiss Federal Department of Finance, 2021) Critics argued that it was unfair. However, it turned out to be very unpopular and was soon repealed in several cantons, with others implementing stricter guidelines. What the British and Swiss examples show is that taxation always and everwhere involves a tradeoff between efficiency and equity. A lump sum tax is efficient, however it is not equitable and that is why it is rarely implemented with popular support.

The foregoing were examples of previous historical attempts internationally to implement a LST. Now, we will turn to current attempts at implementation in the European Union and elsewhere. Paolella and Angelini (2018) show the case of a 2017 LST enacted in Italy to attract high-income foreign individuals to move their tax residence to that country with surprising success. This measure was intended to compete with Portugal, the U.K., and Switzerland. Dobranschi et al. (2017) demonstrate that the European Union (EU) itself was considering in 2017 a lump sum tax on individuals in all 28 member countries as one possible method of public finance reform. The authors compare five different lump sum amounts and none of them would sufficiently cover public expenses on its own. This is one example in which a LST had financial concerns, instead of equity concerns. Additionally, Craciuneanu and Savoiu (2010) find that a Value Added Tax (VAT) would make up for lost revenue more than a lump sum tax would, especially in times of political and financial crisis.

\section{Conclusion}

In conclusion, we have covered the foundations of Optimal Tax Theory (OTT). We have covered the pros and cons of a Lump Sum Tax (LST). We have seen that while a Lump Sum Tax is efficient in that, unlike any other tax, it does not distort relative prices, it is, however, not equitable. A Lump Sum Tax does not addresses issues of fairness: those with more wealth have a greater Ability-To-Pay. The tax disproportionately has a greater impact on low income individuals more than high income individuals, which critics assert only exacerbates economic inequality in society. For that reason, a LST has historically proven to be politically unpopular. Selfinterested politicians seeking re-election are not inclined to pursue such a policy because although it would greatly simplify many countries' tax codes and free consumers to save more for future consumption and investment, the political risks are too great. Where a LST has been successfully implemented tends to be in small and medium-sized European countries where no other tax policy has been deemed feasible. In other words, despite its benefits a LST has only historically been implemented in cases of last resort. Despite these obstacles, OTT shows us that a LST has a lot to provide in terms of maximizing social welfare, perhaps in a 
non-obvious way, which serves as an aggregate of each individual's utility functions. This analysis and comparison and contrast between different views of a LST should be insightful for anyone looking to make the current U.S. tax regime more efficient and to improve social welfare, particularly in a turbulent political environment where other tax reforms are not feasible.

Funding: self-funded.

Author contribution: conceptualization, Richard Fast; data curation, Richard Fast; formal analysis, Richard Fast; funding acquisition, Richard Fast; investigation, Richard Fast; methodology, Richard Fast; software, Richard Fast; supervision, Richard Fast; validation, Richard Fast; visualization, Richard Fast; writing - original draft, Richard Fast; writing - review \& editing, Richard Fast.

\section{References}

1. Slemrod, Joel (1990). Optimal Taxation and Optimal Tax Systems. Journal of Economic Perspectives, 4(1), pp. 157-178. [CrossRef].

2. Slemrod, J. and S. Yitzhaki (1996). The costs of taxation and the marginal efficiency cost of funds. International Monetary Fund Staff Papers, 43(1). [CrossRef].

3. Mirrlees, James, Peter Diamond (1971a). Optimal Taxation and Public Production I: Production Efficiency. American Economic Review. 61, 8-27. [Link].

4. Mirrlees, James, Peter Diamond (1971b). Optimal Taxation and Public Production II: Tax Rules. American Economic Review, 61, 261-278. [Link].

5. Mankiw, N. Gregory, Weinzierl, Matthew, Yagan, Danny (2009). Optimal Taxation in Theory and Practice. Journal of Economic Perspectives, 23 (4), 147-174. [Link].

6. Ramsey, Frank (1927). A Contribution to the Theory of Taxation. Economic Journal, 37 (145), 47-61. [Link].

7. Swiss Federal Department of Finance (2021). Lump-sum taxation. [Link]. Accessed Nov. 7, 2021.

8. Samuelson, Paul A. (1954). The Pure Theory of Public Expenditure. The Review of Economics and Statistics, 36(4), 387-389. MIT Press. [CrossRef].

9. Black, John, et al. (2009). A Dictionary of Economics. Oxford University Press. 3rd Ed. [CrossRef].

10. Lindahl, Erik (1958) [1919]. Just taxation - A positive solution. In Musgrave, R. A.; Peacock, A. T. (eds.), Classics in the Theory of Public Finance, London: Macmillan. [Link].

11. Lindahl, Erik (1958). Some Controversial Questions in the Theory of Taxation. [Link].

12. Paolella, Carlo Maria, and Luca Angelini (2018). Encouraging Experiences of Application for the Italian Lump-Sum Tax Regime. International Tax Journal, 44(6), 25-28. [Link]. Accessed November 14, 2021.

13. Petre, Mihaela Cosmina, and Cristina Bunea Bontas (2009). Impact of Lump-Sum Tax in Romania. Romanian Economic and Business Review, 4(4), 157-164. [Link]. Accessed November 14, 2021.

14. Dobranschi, Marian, et al. (2017). Future EU Funding: A Case of Lump-Sum Tax. Engineering Economics, 28(4), 376-385. [Link]. Accessed November 14, 2021.

15. Tam, Henry (2004). The Humean Critique of Lump Sum Taxation (or the Implausibility of Pure Lump Sum Taxes in Autocracy). Public Choice, 118(1-2), 61-76. [Link]. Accessed November 14, 2021.

16. Craciuneanu, Viorel, and Gheorghe Savoiu (2010). A Brief History of Taxation and the Solution to the Lump-Sum Tax, in Times of Crisis and Recession. Petroleum-Gas University of Ploiesti Bulletin: Economic Sciences Series, 62(3), 38-47. [Link]. Accessed November 14, 2021.

17. Bishop, Matthew (2004). Lump-Sum Tax. Essential Economics, p. 160. [Link]. Accessed November 14, 2021.

18. Baumol, William, David Bradford (1970). Optimal Departures from Marginal Cost Pricing. The American Economic Review. 60, 265-283, [Link].

19. Mises, Ludwig von [1998, (1949)]. Human Action: A Treatise on Economics. Irvington-on-Hudson, NY: The Foundation for Economic Education. p. 31. [Link].

20. Holcombe, Randall (2006). Public Sector Economics; The Role of Government in the American Economy. New Jersey: Pearson. [Link]. 